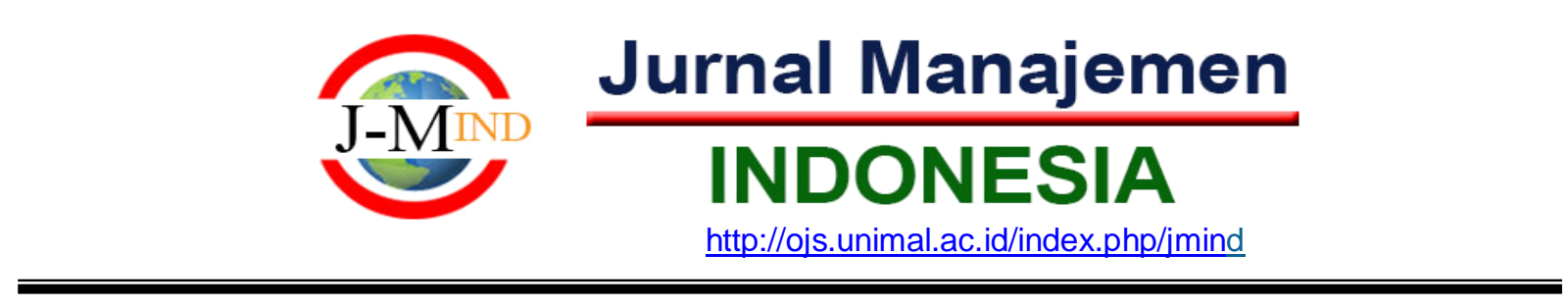

\title{
PENGARUH FAKTOR PENENTU MINAT DAN KEPUTUSAN SISWA DALAM MEMILIH SEKOLAH DI SMK NEGERI 1 PEUREULAK
}

\author{
Mardiana $^{1}$, Mariyudi ${ }^{2 *}$, Rusydi ${ }^{3}$ \\ mardiana@gmail.com ${ }^{1}$,.mariyudi@unimal.ac.id ${ }^{2}$, rusydi@ unimal.ac.id $^{3}$ \\ 123 Program Magister Ilmu Manajemen, FEB, Universitas Malikussaleh Lhokseumaw, Indonesia \\ *coresponding author
}

Keywords

servant leadership,

communication competence,

job satisfaction, employee

performance

\begin{abstract}
This research aims to analyze the influence of servant leadership and communication competence on the facilitators performance of $P K H$ in north Aceh with job satisfaction as the intervening variables. Sampling using the census method with total sample of 150 PKH facilitators in North Aceh. The tool analysis used is Structural Equation Modeling (SEM) with using AMOS. The results of this research show that servant leadership positively influences, but not significantly on job satisfaction and performance. Communication competence significantly and positively influences on satisfaction and performance. Job satisfaction significantly and positively influences on performance. Job satisfaction does not mediate the relationship servant leadership toward performance. Job satisfaction partially mediates the influence of communication competence toward performance.
\end{abstract}

\section{PENDAHULUAN}

Diberlakukannya otonomi pendidikan dalam bentuk MBS (Manajemen Berbasis Sekolah) pada sekitar tahun 2003 menyebabkan persaingan antar lembaga pendidikan semakin kompetitif. Hal tersebut mengakibatkan sekolah sebagai penyelenggara pendidikan berlomba-lomba meningkatkan kredibilitas sekolah untuk menarik minat masyarakat agar memilih/mendaftar di sekolah terkait. Salah satu caranya adalah dengan mendapatkan input (peserta didik) terbaik melalui PPDB.

Saat ini masyarakat mulai sadar arti penting dari sebuah pendidikan. Banyaknya beasiswa perguruan tinggi yang disediakan pemerintah membuat masyarakat ingin menempuh pendidikan tidak cukup sampai sekolah menengah atas saja. Hal ini juga menjadi sebuah tantangan bagi sekolah kejuruan karena pilihan jurusan bagi output (lulusan) SMK saat mendaftar di perguruan tinggi tidak seluas SMA. Tujuan SMK sebagai sekolah pencetak sumber daya manusia (SDM) yang terampil dan siap bekerja juga menambah ketidaktertarikan masyarakat pada sekolah kejuruan. Hal itu dikarenakan peluang lulusan SMK untuk masuk perguruan tinggi lebih sulit. Keterbatasan di atas tentu akan membuat masyarakat lebih memilih SMA dari pada SMK.

Keputusan memilih sekolah merupakan suatu bentuk keputusan pembelian, Sehingga 
proses yang terjadi pada pra pembelian meliputi keseluruhan kegiatan sebelum terjadinya transaksi pembelian dan penggunaan jasa oleh konsumen. Pada tahap pra pembelian konsumen melakukan tiga tahapan yaitu mengidentifikasi kebutuhan, mencari informasi tentang suatu produk, dan melakukan evaluasi altrnatif pilihan. Hal ini dilakukan dengan tujuan mewujudkan kepuasan konsumen setelah transaksi pembelian dengan membandingkan beberapa altenatif alat pemenuh kebutuhan yang memiliki bentuk maupun karakteristik yang sama. (Tjiptono,2014).

Keputusan pemilihan dipengaruhi oleh beberapa faktor diantaranya yaitu minat, kurikulum, peran orang tua dan promosi. Minat merupakan kecenderungan dalam diri individu untuk tertatik pada sesuatu objek atau menyenangi sesuatu objek, Berdasarkan minat yang sesuai dengan pilihannya siswa akan berusaha untuk menjalankan pendidikannya dengan lebih baik dan terarah, minat jugalah yang daya tarik siswa dalam proses pembelajaran. Adapun yang menjadi indikator dalam memtukan minat yaitu: perhatian, ketertarikan, keinginan, keyakinan dan keputusan pembelian.

Hasil penelitian Wibowo (2017) menyatakan bahwa minat berpengaruh positif dan signifikan terhadap keputusan memilih sekolah menengah kejuruan dengan program keahlian elektronika industri di Kabupaten Kulon Progo. Kurikulum merupakan suatu program pendidikan yang berisikan berbagai bahan ajar dan pengalaman belajar yang diprogramkan, direncanakan dan dirancangkan secara sistematika atas dasar norma-norma yang berlaku dan dijadikan pedoman dalam proses pembelajaran bagi pendidik untuk mencapai tujuan pendidikan. Hasil penelitian Hayurika dan Ariel (2015) menyatakan bahwa kurikulum berpengaruh positif dan signifikan terhadap pengambilan keputusan memilih jurusan kuntansi kelas X di SMK N1 Demak.

Peran orang tua adalah sesuatu yang diharapkan oleh anak dari ayah dan ibunya, orang tua dalam keluarga berperan sebagai guru, penuntun, pengajar, serta sebagai pemimpin pekerjaan dan pemberi. Menurut Lestari (2012) ibu berperan membentuk keyakinan (belief)tentang pentingnya kepercayaan, sedangkan ayah berperan membentuk perilaku mempercayai (trusting behavior). Berdasarkan pendapat tersebut maka akan lebih baik jika ayah dan ibu saling bekerja sama dan saling mendukung dalam mengasuh dan mendidik anakanaknya. Karena ibu dapat memberikan keyakinan atau keteguhan tentang hal-hal yang baik sedangkan ayah dapat memberi contoh tentang hal-hal yang baik.

Menurut Tjiptono (2008) salah satu faktor yang mendorong terciptanya keberhasilan pemasaran adalah promosi, melaui promosi informasi tentang suatu produk dapat diketahui oleh konsumen. Promosi menjadi suatu alternatif dalam menarik minat konsumen untuk membeli suatu produk. Promosi adalah seni untuk merayu pelanggan dan calon konsumen untuk membeli lebih banyak produk perusahaan. Promosi salah satu variabel di dalam bauran pemasaran yang sangat penting dilaksanakan oleh perusahaan dalam pemasaran produk atau jasanya.

Promosi merupakan salah satu faktor penentu keberhasilan suatu program pemasaran. Betapapun berkualitasnya suatu produk, bila konsumen belum pernah mendengarnya dan tidak yakin bahwa produk itu akan berguna bagi mereka, maka mereka tidak akan pernah membelinya. Namun indikator yang digunakan dalam penentuan promosi yaitu pesan promosi, media promosi, waktu promosi dan frekuensi promosi.

Persaingan yang semakin tinggi tersebut hendaknya tidak menjadi suatu kendala bagi 
pertumbuhan lembaga pendidikan. Salah satu upaya dalam mengembangkan pendidikan dapat dilakukan melalui strategi pemasaran. Dengan menggunakan strategi yang tepat lembaga pendidikan mampu meningkatkan kualitas dan eksistensi nya dengan bertambahnya minat siswa yang mendaftar di sekolah tersebut. Saat ini keahlian sangat dibutuhkan dalam dunia kerja sehingga banyak peserta didik yang tertarik untuk melanjutkan pendidikan ke Sekolah Menengah Kejuruan (SMK).

Berdasarkan hasil pengamatan dilapangan mengindikasikan bahwa keputusan memilih sekolah SMK Negeri 1 Peureulak sudah mulai menurun. Hal ini dipengaruhi oleh harga (biaya pendidikan). Biaya pendidikan merupakan salah satu elemen penting untuk melancarkan penyelenggaraan pendidikan, hal ini guna memfasilitasi berjalannya kebijakan program sekolah. Namun tingginya biaya pendidikan saat ini menyebabkan siswa Memilih mencari biaya sekolah yang murah, kondisi ekonomi keluarga dan biaya transportasi yang murah. Ini didukung hasil penelitian Murdopo (2013), bahwa terdapat hubungan yang positif antara preferensi masyarakat dalam memilih sekolah dengan biaya sekolah. Utami dan Mukodim (2012) juga mengungkapkan bahwa biaya berpengaruh terhadap keputusan mahasiswa.

Promosi juga merupakan faktor penting yang harus diperhatikan. Adanya promosi dari sekolah merupakan salah satu sumber informasi yang dapat mempengaruhi keputusan memilih siswa. Promosi akan memberikan informasi berupa pengetahuan baru mengenai rincian detail sekolah yang diperlihatkan melalui gambar dan keterangan. Informasi ini akan diproses dengan pengelaman yang dimiliki baik dari dirinya sendiri maupun dari orang lain, sehingga akan menentukan penilaian terhadap SMK N 1 Peureulak .

Adanya promosi juga akan menentukan perasaan suka atau pun tidak suka terhadap SMK N 1 Peureulak. Bila promosi yang diberikan SMK N 1 Peureulak dapat menarik minat calon siswa-siswa baru, maka siswa akan merasa suka dan puas terhadap SMK N 1 Peureulak sehingga akan dilanjutkan pada keputusan memilih untuk sekolah SMK N 1 Peureulak. SMK N 1 Peureulak melakukan promosi dengan penyebaran brosur di lingkungan Sekolah Menengah Pertama (SMP). Melihat dari kegiatan promosi yang diterapkan oleh SMK N 1 Peureulak sebenarnya tidaklah jauh berbeda dengan sekolah SMK Negeri yang lain, tetapi masyarakat untuk memilih SMK ini sudah cukup banyak berkurang dibandingkan dengan SMK lainnya.

Berdasarkan latar belakang permasalahan diatas yang telah diuraikan, maka penulis tertarik melakukan penelitian tentang minat dan keputusan dalam memilih sekolah SMK faktor-faktor yang dapat mempengaruhinya. Hal inilah yang menjadi dasar penulis mengambil judul "Pengaruh Faktor Penentu Minat dan Keputusan Siswa dalam Memilih Sekolah di SMK Negeri 1 Peureulak".

\section{Perumusan Masalah Penelitian}

Berdasarkan fenomen dan pada latar belakang, serta rumusan masalah dalam penelitian ini adalah :

1. Bagaimanakah pengaruh kurikulum terhadap minat siswa dalam memilih sekolah SMKN 1 Peureulak?

2. Bagaimanakah pengaruh peran orang tua terhadap minat siswa dalam memilih sekolah SMKN 1 Peureulak ? 
3. Bagaimanakah pengaruh promosi terhadap minat siswa dalam memilih sekolah SMKN 1 Peureulak?

4. Bagaimanakah pengaruh minat terhadap keputusan siswa dalam memilih sekolah SMKN 1 Peureulak?

5. Bagaimanakah pengaruh kurikulum terhadap keputusan siswa dalam memilih sekolah SMKN 1 Peureulak?

6. Bagaimanakah pengaruh peran orag tua terhadap keputusan siswa dalam memilih sekolah SMKN 1 Peureulak?

7. Bagaimanakah pengaruh promosi terhadap keputusan siswa dalam memilih sekolah SMKN 1 Peureulak?

8. Apakah minat memediasi hubungan antara kurikulum terhadap keputusan siswa dalam memilih sekolah SMKN 1 Peureulak?

9. Apakah minat memediasi hubungan antara peran orang tua terhadap keputusan siswa dalam memilih sekolah SMKN 1 Peureulak?

10. Apakah minat memediasi hubungan antara promosi terhadap keputusan siswa dalam memilih sekolah SMKN 1 Peureulak?

\section{Tujuan Penelitian}

Berdasarkan rumusan masalah di atas, maka tujuan dari penelitian ini adalah:

1. Untuk mengetahui pengaruh kurikulum terhadap minat siswa dalam memilih sekolah SMKN 1 Peureulak

2. Untuk mengetahui pengaruh peran orang tua terhadap minat siswa dalam memilih sekolah SMKN 1 Peureulak.

3. Untuk mengetahui pengaruh promosi terhadap minat siswa dalam memilih sekolah SMKN 1 Peureulak.

4. Untuk mengetahui pengaruh minat terhadap keputusan siswa dalam memilih sekolah SMKN 1 Peureulak.

5. Untuk mengetahui pengaruh kurikulum terhadap keputusan siswa dalam memilih sekolah SMKN 1 Peureulak.

6. Untuk mengetahui pengaruh peran orang tua terhadap keputusan siswa dalam memilih sekolah SMKN 1 Peureulak.

7. Untuk mengetahui pengaruh promosi terhadap keputusan siswa dalam memilih sekolah SMKN 1 Peureulak.

8. Untuk mengetahui minat memediasi pengaruh hubungan kurikulum terhadap terhadap keputusan siswa dalam memilih sekolah SMKN 1 Peureulak.

9. Untuk mengetahui minat memediasi pengaruh hubungan peran orang tua terhadap terhadap keputusan siswa dalam memilih sekolah SMKN 1 Peureulak.

10. Untuk mengetahui minat memediasi pengaruh hubungan promosi terhadap terhadap keputusan siswa dalam memilih sekolah SMKN 1 Peureulak.

Manfaat Penelitian

Manfaat Teoritis 
Manfaat teoretis dalam penelitian ini adalah sebagai berikut:

1. Dalam rangka mengembangkan wawasan dan pengetahuan penelitian dengan mendapatkan gambaran tentang faktor - faktor penentu minat dan keputusan siswa dalam memilih sekolah.

2 Bahan rujukan bagi para peneliti yang ingin membahas tentang faktor - faktor penentu minat dan keputusan siswa dalam memilih sekolah.

\section{Manfaat Praktis}

1 Sebagai sumbangan pemikiran dalam upaya memperkaya ilmu pengetahuan, khususnya dalam penelitian terhadap faktor - faktor penentu minat dan keputusan siswa dalam memilih sekolah.

2 Bagi peneliti, dapat memberikan manfaat untuk memperdalam ilmu Sumber daya manusia yang telah dipelajari agar dapat diterapkan untuk meningkatkan kinerja di masa yang akan datang.

\section{Kajian Pustaka}

\section{Kurikulum}

Menurut Dakir (2010) kurikulum berarti suatu program pendidikan yang berisikan berbagai bahan ajar dan pengalaman belajar yang diprogramkan, direncanakan dan dirancangkan secara sistematika atas dasar norma-norma yang berlaku dan dijadikan pedoman dalam proses pembelajaran bagi pendidik untuk mencapai tujuan pendidikan. Sedangkan menurut Suryosubroto (2010) kurikulum adalah segala pengalaman pendidikan yang diberikan oleh sekolah kepada seluruh anak didiknya, baik dilakukan di dalam sekolah maupun di luar sekolah.

Menurut Nurgiantoro (2013) kurikulum merupakan alat untuk mencapai tujuan tertentu dalam pendidikan. Kurikulum dan pendidikan adalah dua hal yang sangat erat kaitannya, tidak dapat dipisahkan satu sama yang lain. Kemendikbud (2013) kurikulum adalah instrumen pendidikan untuk membawa insan Indonesia agar memiliki komponen pendidikan yang disusun secara relevan atas dasar tujuan, program pendidikan, sistem penyampaian dan evaluasi oleh sekolah dan guru yang mengajar.

Dari beberapa definisi dapat disimpulkan bahwa kurikulum adalah suatu rancangan pendidikan bagi pengalaman belajar anak dan remaja di sekolah, kurikulum merupakan rancangan induk yang meliputti semua pengalaman sekolah yang didalamnya terintegrasi nilai-nilai, filsafat, keyakinan serta pelaksanaan pendidikan kurikulum disusun oleh para pendidik, ahli-ahli serta orang dewasa lainnya dalam masyarakat dan negara serta ditujukan yang dicita-citakan dan bermanfaat bagi individu serta masyarakat.

\section{Peran Orang Tua}

Menurut Moeliono (2008) Kata orang tua merupakan kalimat majemuk, yang secara leksikal berarti “Ayah ibu kandung: orang yang dianggap tua (cerdik, pandai, ahli dan sebagainya), orang-orang yang dihomati (disegani), sedangkan menurut Rahmat (2015) ialah seseorang yang telah melahirkan dan mempunyai tanggung jawab terhadap anak-anak baik anak sendiri maupun anak yang diperoleh melalui jalan adopsi.

Menurut Ahmadi (2011) "Peran adalah suatu kompleks pengharapan manusia terhadap 
caranya individu harus bersikap dan berbuat dalam situasi tertentu berdasarkan status dan fungsi sosialnya". Sedangkan menurut Soekanto (2012) "Peranan merupakan aspek dinamis kedudukan". Berdasarkan pendapat-pendapat tersebut, maka peran merupakan sesuatu yang diharapkan dari seseorang yang berkenaan dengan caranya, sikap dan perbuatan berdasarkan kedudukan sosial yang dimilikinya, sehingga jika seseorang telah melaksanakan hak-haknya dan kewajibannya, maka ia sudah menjalankan perannya

Dari beberapa definisi diatas dapat disimpulkan bahwa orang tua merupakan kelompok kecil yang umumnya terdiri atas ayah, ibu dan anak-anak. Hubungan antar anggota keluarga dijiwai oleh suasana afeksi dan rasa tanggung jawab dan hubungan sosial di antara anggota keluarga relatif tetap dan didasarkan atas ikatan darah, perkawinan atau adopsi. Umumkan orang tua berkewajiban memelihara, merawat, dan melindungi anak dalam rangka sosialisasinya agar meraka mampu mengendalikan diri dan berjiwa social.

\section{Kepuasan Kerja}

Handoko (2009) mendefinisikan kepuasan kerja sebagai keadaan emosional yang menyenangkan atau tidak menyenangkan dimana para karyawan memandang pekerjaannya. Hal ini tampak dalam sikap positif pekerja terhadap pekerjaan yang dihadapi dan lingkungannya. Sebaliknya, karyawan yang tidak puas akan bersikap negatif terhadap pekerjaan dan bentuk yang berbeda beda satu dengan yang lainnya.

Robbins dan Judge (2015) menyatakan bahwa karyawan akan merasa puas bila tidak ada perbedaan (discrepancy) antara yang diinginkan dengan persepsinya terhadap kenyataan. Ukuran kepuasan didasarkan pada kenyataan yang dihadapi dan diterima sebagai kompensasi usaha dan tenaga yang diberikan. Kepuasan kerja tergantung dari keseimbangan (equity) antara yang diharapkan dengan kenyataan.

Dapat disimpulkan bahwa kepuasan kerja merupakan keadaan emosional yang menyenangkan atau tidak menyenangkan dalam memandang sebuah pekerjaannya. Semakin tinggi tingkat kepuasan kerja maka akan semakin tinggi pula kinerja karyawan begitu juga ketidakpuasan kerja akan berimplikasi kepada menurunnya kinerja karyawan.

\section{Promosi}

Menurut Nickels dalam Swastha \& Irawan (2008:349), promosi adalah arus informasi atau persuasi satu arah yang dibuat untuk mengarahkan seseorang atau organisasi kepada tindakan yang menciptakan pertukaran dalam pemasaran. Metode-metode yang digunakan dalam kegiatan promosi tersebut terdiri atas periklanan, promosi penjualan, penjualan perseorangan dan hubungan masyarakat. Promosi menunjuk pada berbagai aktivitas yang dilakukan perusahaan untuk mengkomunikasikan kebaikan produknya dan membujuk para pelanggan dan konsumen sasaran untuk membeli produk tersebut. Sehingga dapat disimpulkan mengenai promosi yaitu dasar kegiatan promosi adalah komunikasi perusahaan dengan konsumen untuk mendorong terciptanya penjualan.

Promosi menurut Alma (2006) adalah : "Promosi adalah sejenis komunikasi yang memberi penjelasan dan meyakinkan calon konsumen mengenai barang dan jasa dengan tujuan untuk memperoleh perhatian, mendidik, mengingatkan dan meyakinkan calon konsumen".

Dari beberapa defenisi diatas dapat di simpulkan bahwa Promosi merupakan alat 
komunikasi dan penyampaian pesan yang dilakukan baik oleh perusahaan maupun perantara dengan tujuan memberikan informasi mengenai produk, harga dan tempat. Informasi itu bersifat memberitahukan, membujuk, mengingatkan kembali kepada konsumen, para perantara atau kombinasi keduanya. Dalam promosi juga, terdapat beberapa unsur yang mendukung jalannya sebuah promosi tersebut yang biasa disebut bauran promosi.

\section{Minat}

Minat adalah suatu keadaan dimana seseorang mempunyai perhatian terhadap sesuatu dan disertai keinginan untuk mengetahui dan mempelajari maupun membuktikan lebih lanjut Walgito (2001). Winkel (2016) mengatakan bahwa minat adalah kecenderungan yang agak menetap untuk merasa tertarik pada bidang-bidang tertentu dan merasa senang berkecimpung dalam bidang itu, sedangkan menurut Witherington (2006) minat adalah kesadaran seseorang terhadap suatu objek, seseorang, suatu soal atau situasi tertentu yang mengadung sangkut paut dengan dirinya atau dipandang sebagai sesuatu yang sadar.

\section{Pengambilan Keputusan}

Menurut Terry (2014) Pengambilan keputusan adalah pemilihan alternative perilaku (kelakuan) tertentu dari dua atau lebih alternatif yang ada. Sedangkan menurut Siagian (2014) Pengambilan keputusan adalah suatu pendekatan yang sistematis terhadap hakikat alternatif yang dihadapi dan mengambil tindakan yang menurut perhitungan merupakan tindakan yang paling tepat. Namun menurut (2010) Pengambilan keputusan adalah proses yang digunakan untuk memilih suatu tindakan sebagai cara pemecahan masalah.

Menurut Salusu (2004), pengambilan keputusan adalah suatu proses memilih alternatif cara bertindak dengan metode yang sesuai dengan situasi. Sedangkan Jannis \& Mann (2010) menyebutkan bahwa pengambilan keputusan merupakan pemecahan masalah dan terhindar dari faktor situasional. Dari beberapa definisi diatas dapat disimpilkan bahwa pengambilan keputusan merupakan suatu proses pemilihan alternatif terbaik dari beberapa alternatif secara sistematis untuk ditindaklanjuti (digunakan) sebagai suatu cara pemecahan masalah

\section{Kerangka Konseptual}

Kerangka konseptual yang dibentuk dalam penelitian ini didasarkan pada tinjauan pustaka dan masalah penelitian yang telah diuraikan pada bagian terdahulu. Minat merupakan konsep yang harus diperhatikan dalam suatu keputusan pemilihan yang akan diambil.

Hasil penelitian yang dilakukan oleh Hayurika dan Arief (2015) menunjukkan bahwa variabel perbedaan gender (dimensi kontrol, kurangnya partisipan, dimensi manfaat, dimensi proses pembelajaran, kurangnya keterwakilan dan perlakuan tidak baik), variabel faktor internal (potensi diri, intelegensi dan bakat) seta variabel faktor eksternal (kesempatam kerja, sekolah, teman sebaya dan orang tua) berpengaruh positif dan signifikan terhadap minat dalam pengambilan keputusan memilih jurusan akuntansi kelas X di SMK N 1 Demak.

Kamanjaya et al. (2017) hasil penelitian menunjukkan bahwa kurikulum berpengaruh positif dan signifikan terhadap minat studi lanjut siswa tingkat lulusan SMA dan SMK di Jurusan Pendidikan Teknik Informatika Undiksha, dengan koefisien korelasi R sebesar 0,175, nilai probabilitas 0.023 dan kontribusi sebesar 31\% dan sebanyak 69\% yang tidak memberikan kontribusi. serta penerimaan mahasiswa baru berpengaruh positif dan signifikan 
terhadap minat terhadap minat studi lanjut siswa tingkat lulusan SMA dan SMK di Jurusan Pendidikan Teknik Informatika, dengan koefisien korelasi R sebesar 0,598, nilai probabilitas 0.000 dan kontribusi sebesar 35,8\% dan sebanyak 64,2\% tidak berkontribusi.

Sari et al. (2015) hasil penelitian menunjukkan bahwa citra sekolah yang dimensi utamanya yaitu produk, harga, tempat, promosi, dan orang, serta kurikulum, dimana produk, promosi dan kurikulum berpengaruh positif dan signifikan terhadap keputusan memilih sekolah pada siswa SMK Kristen 1 Surakarta. sedangkan variabel harga, tempat dan orang tidak berpengaruh terhadap keputusan memilih sekolah pada siswa SMK Kristen 1 Surakarta. sedangkan variabel.

Widiarto et al. (2018) hasil penelitian menunjukkan bahwa peran orang tuan berpengaruh positif dan signifikan terhadap keputusan mahasiswa baru dalam memilih program studi diperguruan tinggi, jika peran komunikasi orang tua (X) mengalami peningkatan, akan terjadi kecenderungan peningkatan keputusan mahasiswa dalam memilih program studi di perguruan tinggi (Y) dan demikian pula sebaliknya.

Khasanah (2012) hasil penelitian menunjukkan bahwa ada pengaruh positif yang signifikan antara lokasi sekolah, kepuasan pelanggan, peran orang tua dan budaya sekolah terhadap pengambilan keputusan memilih sekolah. Serta faktor yang dominan dalam mempengaruhi pengambilan keputusan memilih sekolah adalah faktor lokasi sekolah yang berpengaruh sebesar 66,8 persen.

Rakhmanita (2015) hasil peelitian menunjukkan bahwa hasil pengujian hipotesis secara simultan diperoleh bahwa harga, promosi, tempat, dan sarana secara bersama-sama berpengaruh signifikan terhadap keputusan orangtua murid memilih sekolah alam Tangerang. Dan pengaruh keempat variabel tersebut terhadap keputusan orangtua murid memilih sekolah alam Tangerang ternyata cukup besar, hal ini ditunjukkan dengan besarnya angka koefisien adjust determinasi sebesar $77,6 \%$. Sisanya sebesar $22,4 \%$ merupakan pengaruh yang datang dari faktorfaktor lain diluar model ini

Dari uraian kerangka berpikir di atas, maka dapat digambarkan pengaruh dari tiap variabel sebagai berikut:

\section{Gambar Kerangka Konseptual Penelitian}

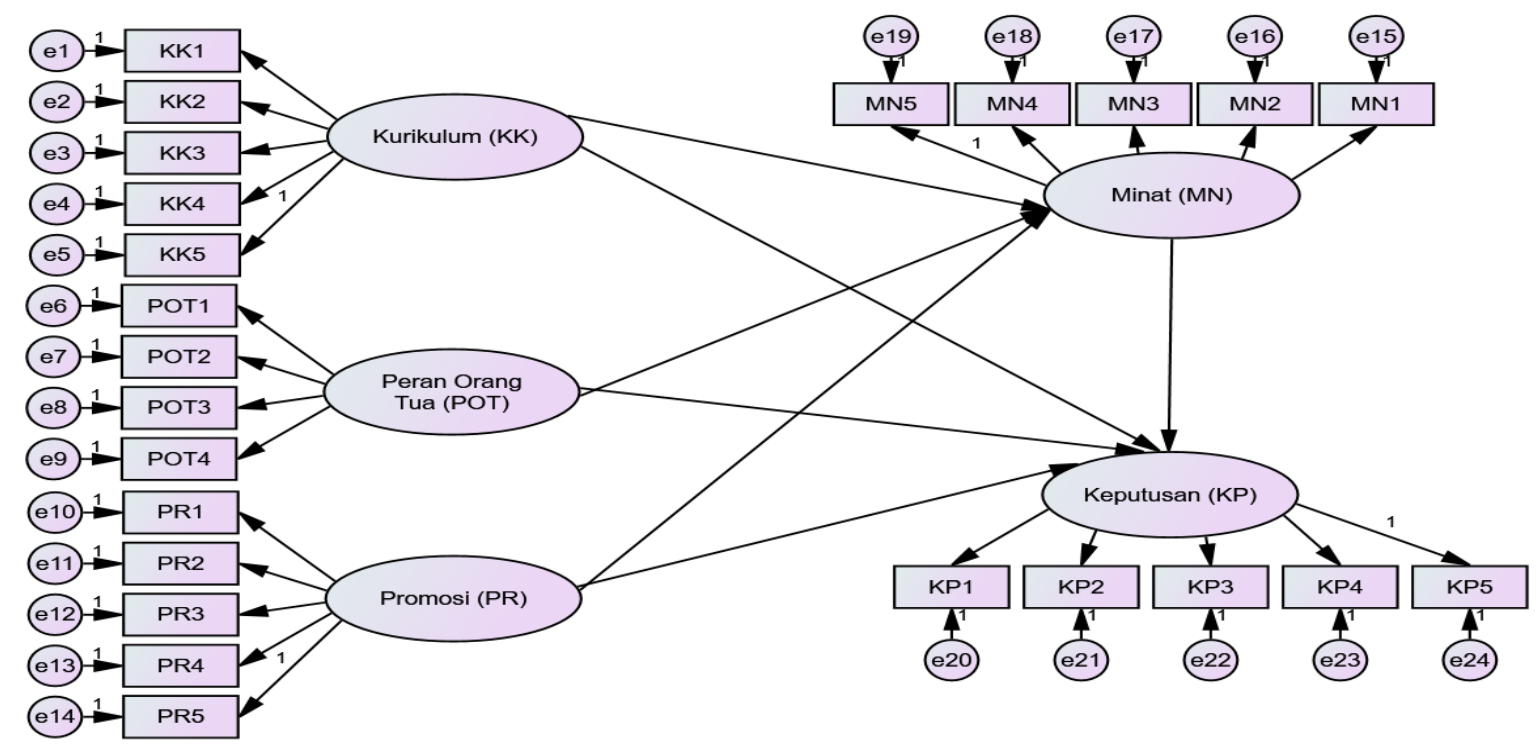




\section{Hipotesis}

Dari kerangka konseptual penelitian, dirumuskanlah hipotesis penelitian sebagai berikut:

\begin{tabular}{|c|c|c|}
\hline $\mathrm{H}_{1}$ & : & $\begin{array}{l}\text { Kurikulum berpengaruh } \\
\text { terhadap minat siswa dalam } \\
\text { memilih sekolah di SMKN } 1 \\
\text { Peureulak }\end{array}$ \\
\hline $\mathrm{H}_{2}$ & : & $\begin{array}{l}\text { Peran orang tua berpengaruh } \\
\text { terhadap minat siswa dalam } \\
\text { memilih sekolah di SMKN } 1 \\
\text { Peureulak }\end{array}$ \\
\hline $\mathrm{H}_{3}$ & : & $\begin{array}{l}\text { Promosi berpengaruh terhadap } \\
\text { minat siswa dalam memilih } \\
\text { sekolah di SMKN } 1 \text { Peureulak }\end{array}$ \\
\hline $\mathrm{H}_{4}$ & : & $\begin{array}{l}\text { Minat berpengaruh terhadap } \\
\text { keputusan siswa dalam memilih } \\
\text { sekolah di SMKN } 1 \text { Peureulak }\end{array}$ \\
\hline $\mathrm{H}_{\mathrm{r}}$ & . & $\begin{array}{l}\text { Kurikulum berpengaruh } \\
\text { terhadap keputusan siswa dalam } \\
\text { memilih sekolah di SMKN } 1 \\
\text { Peureulak }\end{array}$ \\
\hline$U$ & & $\begin{array}{l}\text { Peran orang tua berpengaruh } \\
\text { terhadap keputusan siswa dalam }\end{array}$ \\
\hline
\end{tabular}

$\begin{array}{lll} & & \text { memilih sekolah di SMKN 1 } \\ & & \text { Peureulak } \\ \mathrm{H}_{7} \quad: & \text { Promosi berpengaruh terhadap } \\ & & \text { keputusan siswa dalam memilih } \\ & & \text { sekolah di SMKN 1 Peureulak } \\ \mathrm{H}_{8} \quad: \quad & \text { Kurikulum berpengaruh } \\ & \text { terhadap keputusan siswa dalam } \\ & \text { memilih sekolah di SMKN 1 } \\ & \text { Peureulak dengan minat sebagai } \\ & \text { variabel intervening } \\ \mathrm{H}_{9} \quad: \quad & \text { Peran orang tua berpengaruh } \\ & \text { terhadap keputusan siswa dalam } \\ & \text { memilih sekolah di SMKN 1 } \\ & \text { Peureulak dengan minat sebagai } \\ & \text { variabel intervening } \\ & \text { Promosi berpengaruh terhadap } \\ & \text { keputusan siswa dalam memilih } \\ & \text { sekolah di SMKN 1 Peureulak } \\ & \text { dengan minat sebagai variabel } \\ & \text { intervening }\end{array}$

Metode Penelitian

\section{Objek dan Lokasi Penelitian}

Objek dalam penelitian ini adalah siswa yang memilih bersekolah di SMKN 1 Peureulak. Ruang lingkup penelitian adalah variabel harga, lokasi, promosi, keputusan memilih dan minat. Adapun yang menjadi lokasi dalam penelitian ini dilakukan di Peureulak.

\section{Populasi dan Sampel}

Populasi dalam penelitian ini adalah peserta didik baru di SMKN 1 Peureulak yang berjumlah 641 peserta dari tahun 2014-2018. Penentuan sampel dengan menggunakan rumus Slovin. Dengan demikian jumlah sampel penelitian ini adalah sebanyak 246 responden.

\section{Teknik Pengumpulan Data}

Teknik pengumpulan data yang digunakan dalam penelitian ini adalah dengan menyebarkan kuesioner kepada responden penelitian dan pengukurannya dengan menggunakan Skala Likert.

\section{Pengujian Instrumen Penelitian}

Ghozali (2011) menyatakan bahwa uji kualitas data terdiri dari uji validitas dan uji reliabilitas. 
1. Uji Validitas

Data yang valid adalah data yang tidak berbeda antara data yang dilaporkan oleh peneliti dengan data yang sesungguhnya terjadi pada objek penelitian. Dalam SEM pengujian validitas dilakukan dengan Confirmatory Factor Analysis (CFA). Suatu indikator dikatakan valid apabila nilai loading factor untuk setiap butir indikatornya lebih besar 0,60 (Ghozali, 2014).

2. Uji Reliabilitas

Pada dasarnya uji reliabilitas menunjukan sejauhmana suatu alat ukur dapat memberikan hasil yang relatif sama bila dilakukan pengukuran kembali pada subjek yang sama. Uji reliabilitas dilakukan dengan dua cara yaitu Construct Reliability (CR) dan Variance Extracted (VE). Nilai batas yang digunakan untuk menilai Construct Reliability (CR) adalah 0,70. Sedangkan nilai Variance Extracted (VE) direkomendasikan pada tingkat paling sedikit 0,50 .

\section{Metode Analisis Data}

Metode analisis data yang akan digunakan dalam penelitian ini adalah Structural Equation Modelling (SEM) yang dioperasikan melalui program Analysis of Moment Structure (AMOS).

\section{Hasil Penelitian}

\section{Full Model Sebelum Modifikasi}

Full model SEM sebelum modifikasi bertujuan untuk melihat sejauhmana model dasar yang dibentuk dalam penelitian ini memenuhi kriteria goodness of fit sehingga model dapat menggambarkan fenomena penelitian tanpa adanya modifikasi. Full model SEM sebelum modifikasi ditampilkan dalam gambar berikut ini.

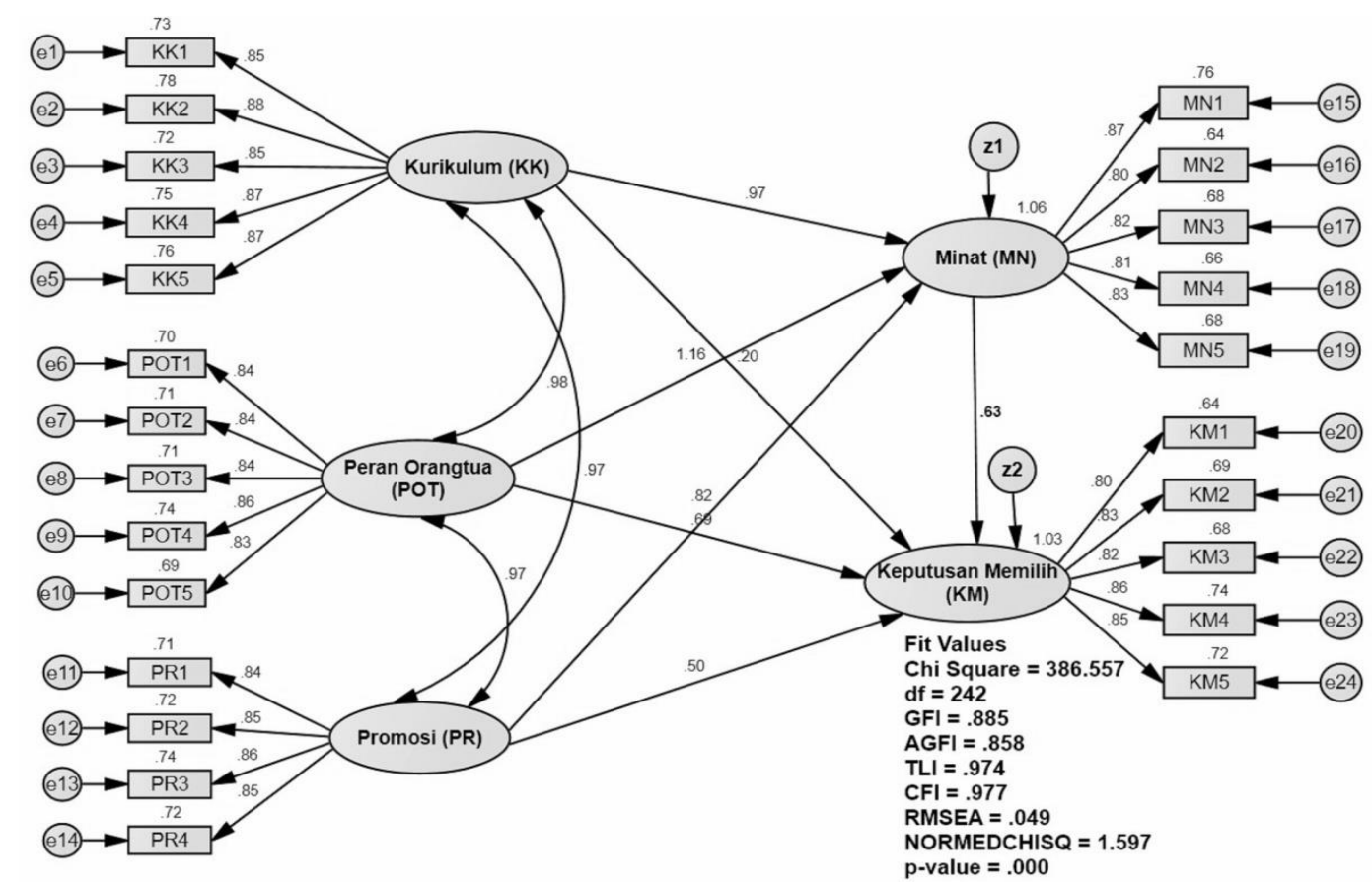

Sumber: Data Kuesioner 2019 Diolah Oleh Peneliti Dengan Program AMOS 
Berdasarkan data gambar di atas dapat dilihat bahwa belum seluruh nilai goodness of fit memenuhi kriteria yang ditentukan, misalnya nilai P-Value masih marginal $(0,000<0,05)$ GFI masih marginal $(0,885<0,90)$ dan nilai AGFI juga masih marginal $(0,858<0,90)$. Dengan demikian model penelitian ini belum menjelaskan model penelitian dengan baik, sehingga model penelitian ini perlu dilakukan modifikasi. Nilai goodness of fit sebelum modifikasi dapat dilihat pada tabel berikut ini.

\section{Tabel Kriteria Goodness Of Fit Model Sebelum Modifikasi}

\begin{tabular}{clrrr}
\hline No & Goodness Of Fit Index & Cut Of Value & Hasil & Kesimpulan \\
\hline 1 & Chi-square $\left(\mathrm{X}^{2}\right)$ & Diharapkan kecil & 386,557 & Baik \\
2 & P-Value & $\geq 0,05$ & 0,000 & Marginal \\
3 & CMIN/DF & $\leq 2,00$ & 1,597 & Baik \\
4 & GFI & $\geq 0,90$ & 0,885 & Marginal \\
5 & AGFI & $\geq 0,90$ & 0,858 & Marginal \\
6 & TLI & $\geq 0,95$ & 0,974 & Baik \\
7 & CFI & $\geq 0,95$ & 0,997 & Baik \\
8 & RMSEA & $\leq 0,08$ & 0,049 & Baik \\
\hline
\end{tabular}

Sumber: Data Kuesioner 2020 Diolah Oleh Peneliti Dengan Program AMOS

\section{Full Model Setelah Modifikasi}

Uji kesesuaian model setelah modifikasi dilakukan dengan cara menghubungkan antar error pada setiap indikator yang disarankan oleh sistem. Tujuannya adalah untuk menaikkan nilai goodness of fit agar model benar-benar layak dan tepat untuk menjelaskan model penelitian. Full model setelah modifikasi dapat dilihat pada gambar berikut ini.

\section{Gambar Full Model Tesis Setelah Modifikasi}

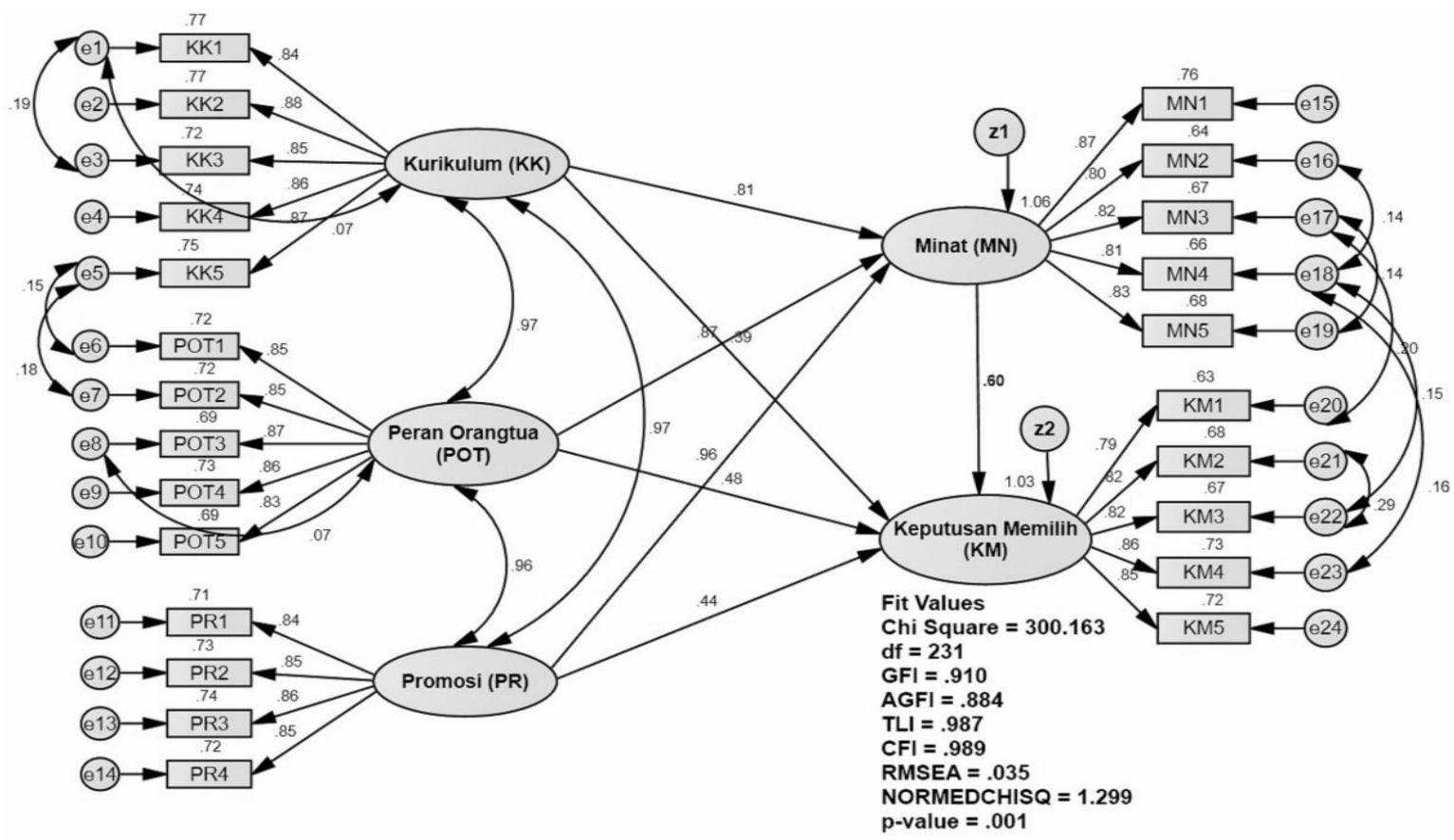

Sumber: Data Kuesioner 2020 Diolah Oleh Peneliti Dengan Program AMOS 
Dari gambar di atas dapat disimpulkan bahwa secara umum semua konstruk yang digunakan untuk membentuk model penelitian ini setelah dimodifikasi telah memenuhi kriteria goodness of fit yang telah ditetapkan seperti nilai Chi-Square nilai GFI, RMSEA, TLI, CFI dan CMIN/DF, kecuali P-Value dan nilai AGFI yang masih marginal, namun sudah bisa ditolerir karena sudah mendekati baik seperti yang terlihat pada table berikut ini.

Tabel Kriteria Goodness Of Fit Full Model SetelahModifikasi

\begin{tabular}{clrrr}
\hline No & Goodness Of Fit Index & Cut Off Value & Nilai Hasil & Kesimpulan \\
\hline 1 & Chi-square $\left(\mathrm{X}^{2}\right)$ & Diharapkan kecil & 300,163 & Baik \\
2 & P-Value & $\geq 0.05$ & 0,01 & Marginal \\
3 & CMIN/DF & $\leq 2.00$ & 1,299 & Baik \\
4 & GFI & $\geq 0.90$ & 0,910 & Baik \\
5 & AGFI & $\geq 0.90$ & 0,884 & Marginal \\
6 & TLI & $\geq 0.95$ & 0,987 & Baik \\
7 & CFI & $\geq 0.95$ & 0,989 & Baik \\
8 & RMSEA & $\leq 0.08$ & 300,163 & Baik \\
\hline
\end{tabular}

Sumber: Data Kuesioner 2020 Diolah Oleh Peneliti Dengan Program AMOS

\section{Pengaruh Variabel Eksogen terhadap Variabel Endogen}

Uji statistik dilakukan dengan mengamati tingkat signifikansi hubungan antar variabel yang ditunjukkan oleh nilai Critical Ratio (C.R). Hubungan yang signifikan ditandai dengan nilai Critical Ratio (C.R) yang lebih besar dari 2,58 dan nilai probabilitas (P) lebih kecil dari 0,05 (Ferdinand, 2014). Apabila hasilnya menunjukkan nilai yang memenuhi persyaratan tersebut, maka hipotesis penelitian diterima dan apabila hasilnya menunjukkan nilai yang tidak memenuhi persyaratan tersebut, maka hipotesis yang diajukan ditolak. Untuk melihat seberapa besar pengaruh variabel servant leadership dan kompetensi komunikasi (eksogen) terhadap variabel kepuasan kerja dan kinerja (endogen) dapat dilihat pada tabel berikut ini.

Tabel Pengaruh Variabel Eksogen Terhadap Variabel Endogen

\begin{tabular}{lll|rrrr}
\hline & & & Std.Est. & S.E. & \multicolumn{1}{c}{ C.R. } & P \\
\hline Minat (MN) & $<---$ & Kurikulum (KK) & 0,315 & 2,846 & 0,004 & 0,315 \\
Minat (MN) & $<---$ & Peran Orang Tua (POT) & 0,258 & 3,519 & $* * *$ & 0,258 \\
Minat (MN) & $<---$ & Promosi (PR) & 0,258 & 3,815 & $* * *$ & 0,258 \\
Keputusan (KM) & $<---$ & Minat (MN) & 0,184 & 2,994 & 0,003 & 0,184 \\
Keputusan (KM) & $<---$ & Kurikulum (KK) & 0,179 & 2,179 & 0,029 & 0,179 \\
Keputusan (KM) & $<---$ & Peran Orang Tua (POT) & 0,228 & 1,996 & 0,046 & 0,228 \\
\hline
\end{tabular}

Sumber: Data Kuesioner 2020 Diolah Oleh Peneliti Dengan Program AMOS

Berdasarkan tabel di atas, maka peneliti menguraikan kesimpulan hasil penelitian untuk menjawab beberapa hipotesis yang telah diajukan dalam penelitian ini. Secara rinci pengajuan hipotesis penelitian akan dibahas secara bertahap sesuai dengan urutan hipotesis yang telah diajukan, yaitu:

a. Pengaruh langsung kurikulum terhadap minat adalah dengan nilai estimate sebesar $0,812(81,2 \%)$ dan nilai signifikan 0,004 lebih kecil dari 0,05 yang berarti pengaruhnya signifikan. 
b. Pengaruh langsung peran orang tua terhadap minat adalah dengan nilai estimate sebesar $0,871(87,1 \%)$ dan nilai signifikan 0,000 lebih kecil dari 0,05 yang berarti pengaruhnya signifikan.

c. Pengaruh langsung promosi terhadap minat adalah dengan nilai estimate sebesar 0,963 (96,3\%) dan nilai signifikan 0,000 lebih kecil dari 0,05 yang berarti pengaruhnya signifikan.

d. Pengaruh langsung minat terhadap keputusan adalah dengan nilai estimate sebesar 0,598 (59,8\%) dan nilai signifikan 0,003 lebih kecil dari 0,05 yang berarti pengaruhnya signifikan.

e. Pengaruh langsung kurikulum terhadap keputusan adalah dengan nilai estimate sebesar $0,385(38,5 \%)$ dan nilai signifikan 0,029 lebih kecil dari 0,05 yang berarti pengaruhnya signifikan.

f. Pengaruh langsung peran oarang tua terhadap keputusan adalah dengan nilai estimate sebesar 0,476 (47,6\%) dan nilai signifikan 0,46 lebih kecil dari 0,05 yang berarti pengaruhnya signifikan.

Pengaruh langsung promosi terhadap keputusan adalah dengan nilai estimate sebesar 0,443 (44,3\%) dan nilai signifikan 0,032 lebih kecil dari 0,05 yang berarti pengaruhnya signifikan.

\section{Pengaruh Total, Langsung dan Tidak Langsung}

Untuk melihat efek mediasi maka terlebih dahulu akan dilihat seberapa besar pengaruh langsung, pengaruh tidak langsung serta pengaruh total variabel servant leadership, kompetensi komunikasi dan kepuasan kerja terhadap kinerja pendamping PKH Aceh Utara seperti yang ditampilkan dalam tabel berikut

Tabel Pengaruh Total, Langsung dan Tidak Langsung

\begin{tabular}{lcccc}
\hline Hubungan Variabel & Kurikulum & Peran Orangtua & Promosi & Minat \\
\hline \multirow{2}{*}{ Minat } & Pengaruh Total & & & \\
Keputusan Memilih & 0,812 & 0,871 & 0,963 & - \\
& 0,870 & 0,996 & 1,018 & 0,598 \\
Minat & Pengaruh Langsung & & & \\
Keputusan Memilih & 0,812 & 0,871 & 0,963 & - \\
& 0,385 & 0,476 & 0,443 & 0,598 \\
Minat & Pengaruh Tidak Langsung & & & - \\
Keputusan Memilih & & - & - & - \\
\hline Sumber: & 0,485 & 0,520 & 0,575 &
\end{tabular}

Sumber: Data Kuesioner 2020 Diolah Oleh Peneliti Dengan Program AMOS

\section{Uji Mediasi (Intervening)}

Baron dan Kenny (1986) menyatakan suatu variabel disebut variabel intervening jika variabel tersebut ikut mempengaruhi hubungan antara variabel independen dan variabel dependen. Salah satu cara yang populer dalam menguji hipotesis mediasi yang dikembangkan adalah uji $\mathrm{Z}$ dari sobel atau yang disebut Zobel Test. 


\section{Minat Memediasi Hubungan Kurikulum Terhadap Keputusan Memilih}

Perhitungan nilai signifikansi jalur -c' dilakukan dengan menggunakan Kalkulator Sobel Test. Hasil pengujian efek mediasi (intervening) hubungan variabel kurikulum dengan variabel keputusan memilih dimediasi oleh variabel kepuasan kerja ditampilkan dalam bentuk gambar.

\begin{tabular}{|c|c|c|c|c|}
\hline \multicolumn{5}{|c|}{ ambar Hasil Uji Sobel Test Kurikulum terhadap Keputusan memilih Dimediasi Oleh minat } \\
\hline Input: & & Test statistic: & Std. Error: & $p$-value: \\
\hline a 0.812 & Sobel test: & 2.01962495 & 0.2404288 & 0.04342231 \\
\hline b 0.598 & Aroian test: & 1.96338023 & 0.24731633 & 0.04960201 \\
\hline$s_{a} 0.315$ & Goodman test: & 2.08099793 & 0.23333805 & 0.0374341 \\
\hline$s_{\mathrm{b}} 0.184$ & Reset all & & Calculate & \\
\hline
\end{tabular}

Sumber: Kuesioner Penelitian 2020 Diolah Dengan Sobel Test

\section{Gambar Pengaruh Kurikulum terhadap Keputusan Memilih yang Dimediasi oleh Minat}

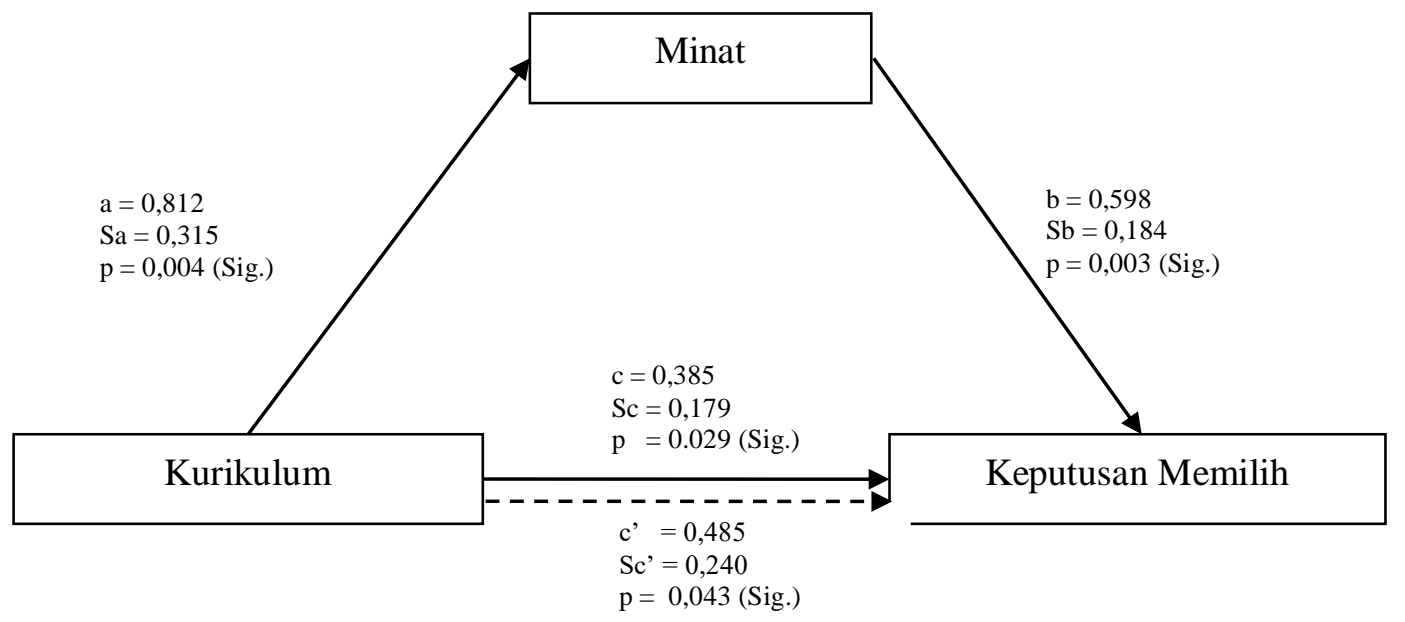

Sumber: Model Mediasi Baron dan Kenny (1986) Dikembangkan Oleh Peneliti

Berdasarkan Gambar diatas dan Kriteria Mediasi (Baron \& Kenny, 1986) dapat disimpulkan bahwa kesemua koefesien jalur langsung (a, b, dan c), adalah signifikan, namun demikian jalur c'adalah signifikan, sehingga dapat disimpulkan terjadi hubungan partial mediation atau dengan kata lain variabel minat memediasi secara partial mediation hubungan antara kurikulum terhadap keputusan memilih dengan nilai estimate standardized dari c' 0,485 dan nilai $p$-values $0,45<0,05$.

\section{Minat Memediasi Hubungan Peran Orang Tua Terhadap Keputusan Memilih}

Perhitungan nilai signifikansi jalur -c' dilakukan dengan menggunakan Kalkulator Sobel Test. Hasil pengujian efek mediasi (intervening) hubungan variabel peran orang tua dengan variabel Keputusan memilih yang dimediasi oleh variabel minat dan ditampilkan dalam bentuk gambar. 
Gambar Hasil Uji Sobel Test Peran Orang Tua terhadap Keputusan Memilih yang Dimediasi oleh Minat

Kuesioner Penelitian 2020 Diolah Dengan Sobel Test

\begin{tabular}{|c|c|c|c|c|}
\hline Input: & & Test statistic: & Std. Error: & $p$-value: \\
\hline a 0.871 & Sobel test: & 2.34136401 & 0.22245922 & 0.01921342 \\
\hline b 0.598 & Aroian test: & 2.28980775 & 0.227468 & 0.02203246 \\
\hline$s_{a} 0.258$ & Goodman test: & 2.39656727 & 0.21733502 & 0.01654946 \\
\hline$s_{b} 0.184$ & Reset all & & Calculate & \\
\hline
\end{tabular}

Gambar Pengaruh Peran Orang Tua Terhadap Keputusan Memilih Yang Dimediasi Oleh Minat

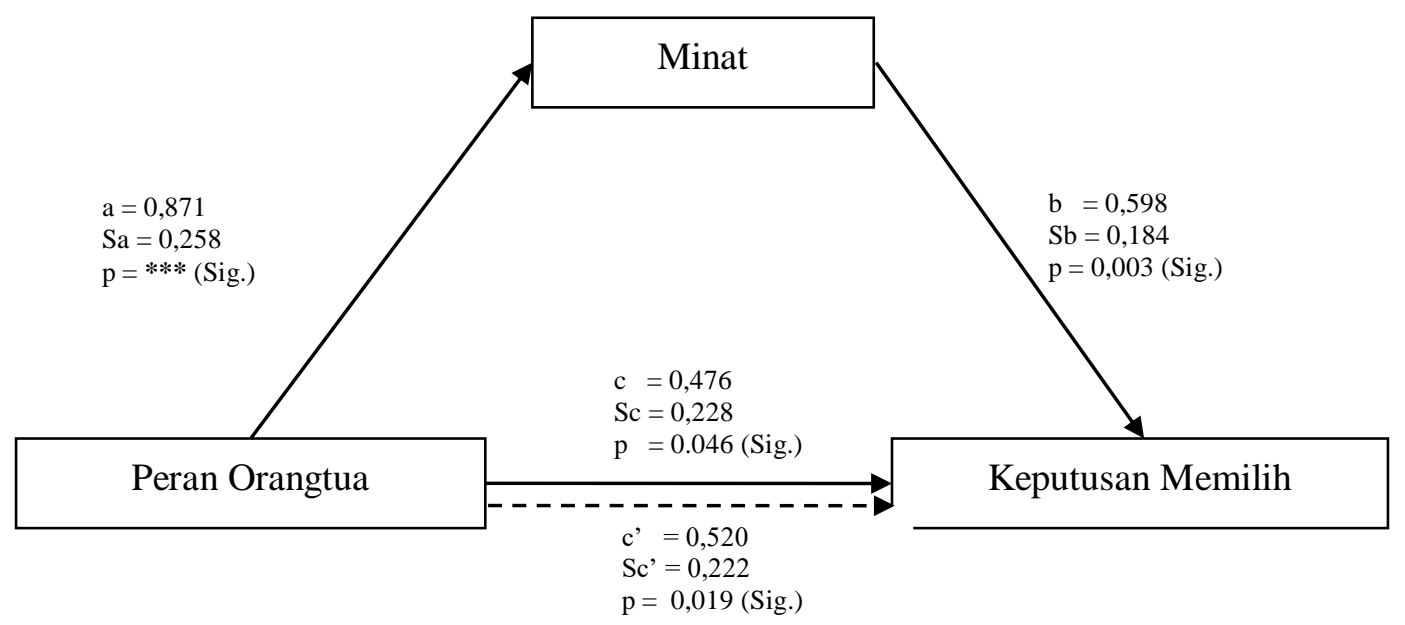

Sumber: Model Mediasi Baron dan Kenny (1986) Dikembangkan Oleh Peneliti

Berdasarkan Gambar diatas dan Kriteria Mediasi (Baron \& Kenny, 1986) dapat disimpulkan bahwa kesemua koefesien jalur langsung (a, b, dan c), adalah signifikan, namun demikian jalur c' adalah signifikan, sehingga dapat disimpulkan terjadi hubungan partial mediation atau dengan kata lain variabel minat memediasi secara partial mediation hubungan antara peran orang tua terhadap keputusan memilih dengan nilai estimate standardized dari c' 0,520 dan nilai $p$-values $0,019<0,05$.

\section{Minat Memediasi Hubungan Promosi Terhadap Keputusan Memilih}

Perhitungan nilai signifikansi jalur -c' dilakukan dengan menggunakan Kalkulator Sobel Test. Hasil pengujian efek mediasi (intervening) hubungan variabel promosi dengan variabel Keputusan memilih yang dimediasi oleh variabel minat dan ditampilkan dalam bentuk gambar.

Gambar Hasil Uji Sobel Test Promosi terhadap Keputusan Memilih yang Dimediasi oleh Minat

\begin{tabular}{|c|c|c|c|c|}
\hline Input: & & Test statistic: & Std. Error: & $p$-value: \\
\hline a 0.963 & Sobel test: & 2.45107014 & 0.23494799 & 0.01424322 \\
\hline$b 0.598$ & Aroian test: & 2.40251869 & 0.23969595 & 0.0162826 \\
\hline$s_{a} 0.258$ & Goodman test: & 2.50268925 & 0.23010208 & 0.01232537 \\
\hline$s_{b} 0.184$ & Reset all & & Calculate & \\
\hline
\end{tabular}


Kuesioner Penelitian 2020 Diolah Dengan Sobel Test

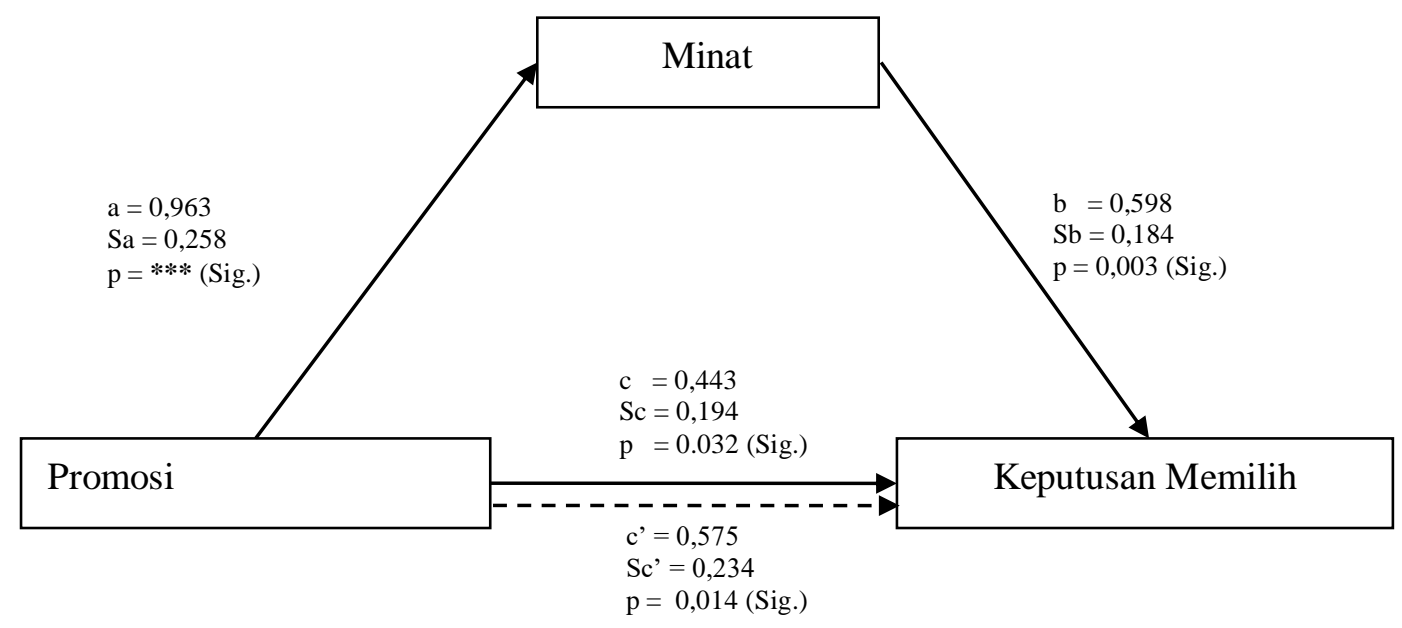

Berdasarkan Gambar diatas dan Kriteria Mediasi (Baron \& Kenny, 1986) dapat disimpulkan bahwa kesemua koefesien jalur langsung (a, b, dan c), adalah signifikan, namun demikian jalur c' adalah signifikan, sehingga dapat disimpulkan terjadi hubungan partial mediation atau dengan kata lain variabel minat memediasi secara partial mediation hubungan antara promosi terhadap keputusan memilih dengan nilai estimate standardized dari c' 0,575 dan nilai $p$-values $0,014<0,05$.

\section{Hasil Uji Hipotesis Penelitian}

Untuk mengetahui apakah penelitian ini menerima atau menolak hipotesis yang telah diajukan, maka akan disajikan kesimpulan dari hasil pengujian hipotesis dalam tabel berikut ini.

Tabel Kesimpulan Hipotesis Penelitian

\begin{tabular}{|c|c|c|c|c|}
\hline \multicolumn{2}{|c|}{ Hipotesis Penelitian } & Std.Est & $\mathrm{P}$ & Kesimpulan \\
\hline $\mathrm{H}_{1}$ & $\begin{array}{l}\text { Kurikulum berpengaruh terhadap } \\
\text { minat siswa dalam memilih sekolah } \\
\text { di SMKN } 1 \text { Peureulak }\end{array}$ & 0,812 & 0.004 & $\begin{array}{l}\text { Diterima (Data } \\
\text { Mendukung Model) }\end{array}$ \\
\hline $\mathrm{H}_{2}$ & $\begin{array}{l}\text { Kurikulum berpengaruh terhadap } \\
\text { keputusan siswa dalam memilih } \\
\text { sekolah di SMKN } 1 \text { Peureulak }\end{array}$ & 0,871 & $* * *$ & $\begin{array}{l}\text { Diterima (Data } \\
\text { Mendukung Model) }\end{array}$ \\
\hline $\mathrm{H}_{3}$ & $\begin{array}{l}\text { Orangtua berpengaruh terhadap minat } \\
\text { siswa dalam memilih sekolah di } \\
\text { SMKN } 1 \text { Peureulak }\end{array}$ & 0,963 & $* * *$ & $\begin{array}{l}\text { Diterima (Data } \\
\text { Mendukung Model) }\end{array}$ \\
\hline $\mathrm{H}_{4}$ & $\begin{array}{l}\text { Orangtua berpengaruh terhadap } \\
\text { keputusan siswa dalam memilih } \\
\text { sekolah di SMKN } 1 \text { Peureulak }\end{array}$ & 0,598 & 0.003 & $\begin{array}{l}\text { Diterima (Data } \\
\text { Mendukung Model) }\end{array}$ \\
\hline $\mathrm{H}_{5}$ & $\begin{array}{l}\text { Promosi berpengaruh terhadap minat } \\
\text { siswa dalam memilih sekolah di } \\
\text { SMKN } 1 \text { Peureulak }\end{array}$ & 0,385 & 0,029 & $\begin{array}{l}\text { Diterima (Data } \\
\text { Mendukung Model) }\end{array}$ \\
\hline
\end{tabular}


Promosi berpengaruh terhadap

$\mathrm{H}_{6} \quad$ keputusan siswa dalam memilih sekolah di SMKN 1 Peureulak

Minat berpengaruh terhadap

$\mathrm{H}_{7} \quad$ keputusan siswa dalam memilih sekolah di SMKN 1 Peureulak Minat siswa memediasi hubungan

$\mathrm{H}_{8} \quad$ antara kurikulum dengan keputusan siswa dalam memilih sekolah di SMKN 1 Peureulak

Minat siswa memediasi hubungan

$\mathrm{H}_{9}$ antara orangtua dengan keputusan siswa dalam memilih sekolah di SMKN 1 Peureulak

Minat siswa memediasi hubungan $\mathrm{H}_{10}$ antara promosi dengan keputusan siswa dalam memilih sekolah di SMKN 1 Peureulak
0,476
0,046
Diterima (Data
Mendukung Model)
0,443
0,032
Diterima (Data
Mendukung Model)
Diterima (Data
0,485
0,043 Mendukung Model)
(Partial Mediation)
0,520
Diterima (Data
0,019 Mendukung Model)
(Partial Mediation)
0,575
Diterimi a
0,014 Mendukuny INodel)
(Partial Mediation)

Sumber: Kuesioner 2020 Diolah Dengan Program AMOS dan Sobel Test

\section{Daftar Referensi}

Ahmadi. (2011). Analisis Faktor-Faktor yang Mempengaruhi Perilaku Konsumen Warung lesehan di Jalan Protokol Yogyakarta”. Jurnal STIE Widya Wiwaha Kajian Bisnis, No. 7, Hlm. 14-28.

Alma, Buchari. (2014). Manajemen Pemasaran Jasa. Penerbit Alfabeta : Bandung.

Arifin, Adyatma. (2012). "Pengaruh Periklanan Terhadap Keputusan Pembelian Konsumen Pasta Gigi Pepsodent Di Kota Makassar”. Jurnal. Universitas Hasanuddin. Makassar.

Astuti, S.W. (2010), Pengaruh Promosi Terhadap Kriteria Pemilihan Sekolah Dan Dampaknya Pada Minat Memilih Jurusan, Journal Of Business And Management, Vol. 1, No. 1, Hal.13-32.

Assauri, Sofjan. (2016). Manajemen Pemasaran. PT. Raja grafindo Persada : Jakarta

Baker, J, Grewel, D., \& Parasuraman, A,(2010). The Influence of Store Environment on Quality Inferences and Store Image. Journal of the Academy of Marketing Science.

Dharmesta \& Handoko. (2010). Manajemen Pemasaran, Analisa Perilaku Konsumen. Yogyakarta: BPFE-Yogyakarta.

Ferdinand, A. (2014). Structural Equation Modelling dalam Penelitian Manajemen. Badan Penerbit Universitas Diponegoro, Semarang. 
Ghozali, I. (2016). Aplikasi Analisis Multivariate dengan Program SPSS. Badan Penerbit Universitas Diponegoro, Semarang.

Hasan, M. Iqbal. (2009). Pokok-pokok Materi Pengambilan Keputusan. Bogor : Ghalia Indonesia.

Hayurika dan Arief (2015) Analisis Faktor-Faktor Yang Mempengaruhi Minat Siswa Dalam Pengambilan Keputusan Memilih Jurusan Akuntansi Kelas X Di SMK N 1 Demak. Jurnal Pendidikan Ekonomi Dinamika Pendidikan Vol. X No. 1

Kotler, Philip. (2012). Manajemen Pemasaran. Jilid 2. Bumi Aksara. Jakarta

Kotler, P, dan Keller, (2016). Manajemen Pemasaran. Edisi 12.Terjemahan. Penerbit Indeks, Jakarta.

Koter, Philip dan Amstrong. (2016).“Marketing Manajemen” Prentice Hal. USA

Lestari. (2012) Pemasaran Dasar. Jakarta : Salemba Empat.

Monroe. (2005). Pricing Making Profitable Decision. New York: The Mc GrawHill Companies, Inc.

Murdopo (2013) Perancangan \& Pengembangan Promosi. Salemba Teknika, Jakarta.

Mukodim. (2012). Pemasaran. Buku I Edisi Pertama. Penerbit Salemba Empat. Jakarta.

Nasution (2013). Manajemen Pemasaran Jasa. Jakarta: Salemba empat. 